\title{
PENGGUNAAN PENDEKATAN CTL UNTUK MENINGKATKAN HASIL BELAJAR SISWA MATERI BAHASAN SEGI EMPAT DAN SEGITIGA
}

\author{
Ardiansyah $^{1}$, Ahmad Zakaria ${ }^{2}$ \\ ${ }^{1}$ IAI AL-KHAIRAT Pamekasan, ${ }^{2}$ STEI-MM Sumber Bungur, Pakong \\ E-mail : a4116047@gmail.com
}

\begin{abstract}
Abstrak:
Tujuan yang ingin dicapai dalam penelitian ini adalah untuk mengetahui aktivitas, respon dan peningkatan hasil belajar siswa kelas VII SMP Negeri Satu Atap 1 Camplong pada materi segi empat dan segitiga. Peneliti ini merupakan penelitian tindakan kelas dimana teknik pengumpulan data dilakukan dengan metode observasi, angket, dan tes. Subjek penelitian ini adalah 37 siswa dari kelas VII di SMP Negeri Satu Atap 1 Camplong Kabupaten Sampang. Dari hasil analisis data, dapat disimpulkan bahwa aktifitas siswa mengalami peningkatan sebesar 0,4 yaitu pada siklus I sebesar 3,2 dan pada siklus II sebesar 3,6 sedangkan respon siswa bernilai positif yaitu dengan memperoleh rata - rata pada siklus I sebesar $77 \%$ dan pada siklus II sebesar 79\%. Kemudian berdasarkan hasil tes secara rata - rata individu mengalami peningkatan sebesar 5 dimana pada siklus I sebesar 70 dan Pada siklus II sebesar 75. Sedangkan secara klasikal juga mengalami peningkatan, dimana pada siklus I mencapai $49 \%$ dan pada siklus II mencapai $86,48 \%$. Jadi, hasil belajar siswa secara klasikal dari siklus I ke siklus II mengalami peningkatan sebesar $37,48 \%$.
\end{abstract}

Kata Kunci: Contextual Teaching and Learning (CTL), Hasil Belajar, SegiEmpat dan Segitiga

\begin{abstract}
:
The purpose of this research is to see the activity, response and increase in learning outcomes of class VII SMP Negeri One Atap 1 Camplong in the material of rectangles and triangles. This researcher is a class action where the data technique is carried out by the method of observation, questionnaires, and tests. The subjects of this study were 37 students from grade VII at SMP Negeri One Atap 1 Camplong Sampang Regency. From the results of data analysis, it can be seen that student activity has increased by 0.4 , namely in cycle I of 3.2 and in cycle II of 3.6, while student responses are positive, namely by obtaining an average in cycle I of $77 \%$ and in cycle II amounted to $79 \%$. Then based on the test results, the average individual has increased by 5 , where in the first cycle of 70 and in the second cycle of 75. Meanwhile, classically it also increased, where in the first cycle it reached $49 \%$ and in the second cycle it reached $86.48 \%$. So, classical student learning outcomes from cycle I to cycle II increased by $37.48 \%$.
\end{abstract}

Keywords: Contextual Teaching and Learning (CTL), Learning Outcomes, Squares and Triangles

\section{Pendahuluan}

Salah satu masalah pokok dalam pembelajaran pada pendidikan formal (sekolah) dewasa ini adalah masih rendahnya daya serap peserta didik. Hal ini menimbulkan rata-rata hasil belajar peserta didik yang senantiasa masih sangat memperihatinkan. Hasil belajar ini tentunya merupakan hasil proses pembelajaran yang masih bersifat konvensional. Pada pembelajaran ini suasana kelas cenderung teacher-centered sehingga siswa menjadi pasif. Selain itu, karena tidak menyentuh ranah dimensi peserta didik itu sendiri, yaitu bagaimana sebenarnya belajar itu (belajar untuk belajar). Dalam arti yang lebih subtansial, bahwa proses pembelajaran hingga dewasa ini masih memberikan dominasi guru dan tidak memberikan akses bagi anak didik untuk berkembang secara mandiri melalui penemuan dan proses berfikirnya (Trianto, 2007).

Apabila kita ingin meningkatkan prestasi, tentunya tidak akan terlepas dari upaya peningkatan kualitas pembelajaran 
disekolah. Satu inovasi yang menarik mengiringi paradigma yang ada adalah ditemukan dan diterapkannya model atau lebih tepat dalam mengembangkan dan menggali pengetahuan peserta didik secara konkrit dan mandiri.

Dengan demikian proses pembelajaran akan lebih variatif, inovatif dan konstruktif dalam mengnstruksi wawasan pengetahuan dan implementasinya sehingga dapat meningkatkan aktifitas dan kreatifitas peserta didik.

Zayyadi (2016) mengatakan bahwa hasil belajar matematika adalah suatu proses perubahan dalam perolehan nilai dari ide-ide (gagasan-gagasan), strukturstruktur, konsep-konsep atau prinsip-prinsip matematika tentang kemajuan siswa dalam segala hal yang dipelajari di sekolah yang menyangkut pengetahuan/keterampilan matematika yang dinyatakan sesudah hasil penilaian.

Matematika merupakan salah satu mata pelajaran yang terkesan sulit bagi siswa. Hal ini sesuai dengan pendapat Zakaria, Budiarto \& Sulaiman (2018) "Math problem-solving skills are not easy for students to do", pernyataan tersebut mengandung arti bahwa keterampilan memecahkan masalah matematika bukan yang mudah dilakukan bagi siswa.

Polya (1973) mengatakan "If you wish to solve a 'problem to prove' you must know, and know very exactly, its principal parts, the hypothesis, and the conclution". Pernyataan tersebut mengandung arti bahwa jika anda ingin memecahkan 'masalah untuk membuktikan' anda harus tahu, dan tahu persis, komponen utama, hipotesis, dan kesimpulan tersebut.

Hal ini disebabkan karena dalam pelajaran matematika siswa sering dihadapkan dengan konsep-konsep atau simbol-simbol yang sulit dipahami. Salah satu karakteristik matematika adalah mempunyai objek yang bersifat abstrak, sehingga menyebabkan banyak siswa mengalami kesulitan dalam belajar matematika. Sehingga menyebabkan kurangnya pemahaman siswa terhadap materi yang dipelajari. Zayyadi (2016) mengatakan bahwa ada pengaruh strategi pembelajaran peningkatan kemampuan berpikir terhadap hasil belajar matematika siswa.

\begin{tabular}{|c|c|}
\hline $\begin{array}{c}\text { Menurut } \\
\text { (2014),keberhasilan }\end{array}$ & proses \\
\hline
\end{tabular}
mengajar matematika tidak terlepas dari persiapan siswa dan persiapan guru. Siswa yang siap belajar matematika akan merasa senang dan dengan penuh perhatian mengikuti pembelajaran tersebut. Oleh karena itu, setiap guru perlu memahami secara baik peran dan fungsi strategi dalam pelaksanaan proses pembelajaran.

Berdasarkan hasil observasi yang dilakukan peneliti sebagai guru matematika di SMP Negeri Satu Atap 1 Camplong, masih ditemukan adanya masalah yaitu rendahnya prestasi belajar matematika yang dicapai siswa. Hal ini mungkin disebabkan oleh proses pembelajaran yang dilakukan berupa metode ceramah sehingga siswa menjadi pasif dalam kegiatan belajar mengajar.

Oleh karena itu peneliti sebagai guru matematika kelas VII di SMP Negeri Satu Atap 1 Camplong, mencoba untuk mencari alternatif pemecahan masalah dengan cara melaksanakan perbaikan pembelajaran dengan menggunakan pembelajaran kooperatif model CTL.

$$
\text { Rusman (2011) menjelaskan }
$$

pembelajaran kontekstual (contextual teaching and learning) adalah konsep belajar yang membantu mengaitkan antara materi yang diajarkannya dengan situasi dunia nyata siswa dan mendorong siswa membantu hubungan antara pengetahuan yang dimilikinya dengan penerapannya dalam kehidupan mereka sehari-hari, dengan melibatkan tujuh komponen utama pembelajaran kontekstual, yakni: 1) Constructivism; 2) Inquiry; 3) Questioning; 4) Learning Community; 5) Modelling; 6) Reflection; dan 7) Authentic Assessment. berikut :

Adapun tujuh komponen sebagai

\section{Konstruktivisme (construktivism)}

Konstruktivisme merupakan landasan berpikir (filosofi) pendekatan CTL, yaitu bahwa pengetahuan dibangun oleh manusia sedikit demi sedikit, yang hasilnya diperluas melalui konteks yang terbatas (sempit). Pengetahuan bukanlah 
seperangkat fakta-fakta, konsep, atau kaidah yang siap untuk diambil dan diingat. Manusia harus mengkonstruksi pengetahuan itu dan memberi makna melalui pengalaman nyata.

Siswa perlu dibiasakan untuk memecahkan masalah, menemukan sesuatu yang berguna bagi dirinya, dan bergelut dengan ide-ide. Guru tidak akan mampu memberikan semua pengetahuan kepada siswa. Siswa harus mengkonstruksikan pengetahuan dibenak mereka sendiri. Dengan dasar itu pembelajaran harus dikemas menjadi proses "mengkonstruksi" bukan "menerima" pengetahuan. Dalam proses pembelajaran, siswa membangun sendiri pengetahuan mereka melalui keterlibatan aktif dalam proses belajar dan mengajar. Siswa menjadi pusat kegiatan, bukan guru.

\section{Inkuiri (Inquiry)}

Menemukan merupakan bagian inti dari kegiatan pembelajaran berbasis CTL. Pengetahuan dan keterampilan yang diperoleh siswa diharapkan bukan hasil mengingat seperangkat fakta-fakta, tetapi hasil dari menemukan sendiri. Guru harus selalu merancang kegiatan yang merujuk pada kegiatan menemukan, apapun materi yang diajarkannya.

Langkah-langkah kegiatan inkuiri adalah sebagai berikut

a. Merumuskan masalah.

b. Mengamati atau melakukan observasi.

c. Menganalisis dan menyajikan hasil dalam tulisan, gambar, laporan, bagan, tabel, dan karya lainnya.

d. Mengkomonikasikan atau menyajikan hasil karya pada pembaca, teman sekelas, guru atau audien yang lain.

e. Bertanya (Questioning)

Bertanya merupakan strategi utama yang berbasis kontekstual. Bertanya dalam pembelajaran dipandang sebagai kegiatan guru untuk mendorong, membimbing dan menilai kemampuan berpikir siswa. Bagi siswa, kegiatan bertanya merupakan bagian penting dalam melaksanakan pembelajaran yang berbasis inquiry, yaitu menggali informasi, mengkonfirmasikan apa yang sudah diketahui, dan mengarahkan perhatian pada aspek yang belum diketahuinya.
Dalam sebuah pembelajaran yang produktif, kegiatan bertanya berguna untuk

a. Menggali informasi, baik administrasi maupun akademis.

b. Mengecek pemahaman siswa.

c. Membangkitkan respon kepada siswa.

d. Mengetahui sejauh mana keingintahuan siswa.

e. Mengetahui hal-hal yang sudah diketahui siswa.

f. Menfokuskan perhatian siswa pada sesuatu yang dikehendaki guru.

g. Untuk membangkitkan lebih banyak lagi pertanyaan dari siswa .

h. Untuk menyegarkan kembali pengetahuan siswa.

\section{Masyarakat belajar (Learning Community)}

Konsep Learning community menyarankan agar hasil pembelajaran diperoleh dari kerjasama dengan orang lain. Dalam kelas CTL, guru disarankan selalu melaksanakan pembelajaran dalam kelompok-kelompok yang anggotanya heterogen. Hasil belajar diperoleh dari "Sharing" antar teman, antar kelompok dan antar yang mengerti dengan yang tidak mengerti.

\section{Pemodelan (Modeling)}

Dalam sebuah pembelajaran keterampilan atau pengetahuan tertentu, ada model yang bisa di tiru oleh siswanya, misalnya guru memodelkan langkahlangkah cara menggunakan rumus matematika. Dalam pembelajaran kontekstual, guru bukan satu satunya model. Pemodelan dapat dirancang dengan melibatkan siswa. Seorang bisa ditunjuk untuk memodelkan sesuatu berdasarkan pengalaman yang diketahuinya. Model dapat juga didatangkan dari luar yang ahli dibidangnya, misalnya mendatangkan seorang perawat untuk memodelkan cara menggunakan thermometer untuk mengukur suhu tubuh pasiennya.

\section{Refleksi (Reflection)}

Refleksi adalah cara berpikir tentang apa yang baru dipelajari atau berpikir kebelakang tentang apa-apa yang sudah kita lakukan di masa yang lalu. Siswa mendapatkan apa yang baru dipelajarinya sebagai struktur pengetahuan yang baru, 
refleksi merupakan respon terhadap kejadian, aktivitas atau pengetahuan yang baru diterima.

\section{Penilaian yang sebenarnya (Authentic Assesment)}

Assesment adalah proses pengumpulan berbagai data yang bisa memberikan gambaran perkembangan belajar siswa (Trianto 2007: 114. Gambaran perkembangan belajar siswa perlu diketahui oleh guru agar bisa memastikan bahwa siswa mengalami proses pembelajaran dengan benar. Apabila data yang dikumpulkan guru mengidentifikasi bahwa siswa mengalami kemacetan dalam belajar. Maka guru segera bisa mengambil tindakan yang tepat agar siswa terbebas dari kemacetan belajar. Karena assesment menentukan proses pembelajaran, maka data yang dikumpulkan harus diperoleh dari kegiatan nyata yang dikerjakan siswa pada saat melakukan proses pembelajaran.

Karakteristik authentic assesment :

a. Dilaksanakan selama dan sesudah proses pembelajaran berlangsung.

b. Bisa digunakan untuk formatif maupun sumatif.

c. Yang diukur keterampilan dan performance, bukan mengingat fakta.

d. Berkesinambungan.

e. Terintegrasi,

f. Dapat digunakan sebagai feed back.

Dengan demikian penggunaan model pembelajaran contextual teaching and learning (CTL) perlu diberikan oleh guru dalam proses belajar, agar dapat mencapai hasil belajar yang lebih baik. Hasil belajar adalah pola-pola perbuatan, nilai-nilai, pengertian-pengertian, sikapsikap, apresiasi dan keterampilan (Suprijono, 2009)

Sedangkan menurut Trianto (2007) pembelajaran pendekatan Contextual Teaching And Learning(CTL) merupakan konsep belajar yang membantu guru mengaitkan antara materi yang diajarkannya dengan situasi dunia nyata siswa dan mendorong siswa membuat hubungan antara pengetahuan yang dimilikinya dengan penerapannya dalam kehidupan mereka sehari hari.
Selain itu, menurut Trianto (2007) siswa perlu dibiasakan untuk memecahkan masalah, menemukan sesuatu yang berguna bagi dirinya, dan bergelut dengan ide-ide. Guru tidak akan mampu memberikan semua pengetahuan kepada siswa. Siswa harus mengkonstruksikan pengetahuan dibenak mereka sendiri. Dengan dasar itu pembelajaran harus dikemas menjadi proses "mengkonstruksi" bukan "menerima" pengetahuan. Dalam proses pembelajaran, siswa membangun sendiri pengetahuan mereka melalui keterlibatan aktif dalam proses belajar dan mengajar. Siswa menjadi pusat kegiatan, bukan guru.

Penerapan CTL dalam kelas cukup mudah. Secara garis besar, langkah-langkah pembelajaran yang menggunakan pendekatan CTL menurut Trianto (2007) yaitu Pertama, kembangkan pemikiran bahwa anak akan belajar lebih bermakna dengan cara bekerja sendiri, menemukan sendiri, dan mengkonstruksi sendiri pengetahuan dan keterampilan barunya. Kedua, laksanakan sejauh mungkin kegiatan inquiry untuk semua topik. Ketiga, kembangkan sifat ingin tahu siswa dengan bertanya. Keempat, ciptakan "masyarakat belajar" (belajar dalam kelompokkelompok). Kelima, hadirkan "model" sebagai contoh pembelajaran. Keenam, lakukan refleksi diakhir pertemuan. Ketujuh, lakukan penilaian yang sebenarnya dengan berbagai cara.

Materi segi empat dan segitiga merupakan materi pelajaran di jenjang Sekolah Menengah Pertama kelas VII yang memaparkan persegi panjang, persegi, segitiga, trapesium, jajargenjang, belah ketupat, layang-layang dan bangun datar tidak beraturan. Sekilas pokok bahasan ini mudah akan dipahami tetapi banyak siswa yang merasa kesulitan ketika memahami atau menyelesaikan soal yang berkaitan dengan segi empat dan segitiga. Oleh sebab itu dibutuhkan suatu aktivitas yang dapat membantu siswa dalam memahami dan menyelesaikan soal. Salah satu model pembelajaran yang dapat membantu meningkatkan daya pikir siswa dalam menyelesaikan soal adalah pendekatan Contextual Teaching And Learning (CTL). 
Berdasarkan uraian di atas peneliti tertarik untuk meneliti dengan tujuan untuk mengetahui peningkatan aktifitas belajar siswa selama pembelajaran pendekatan Contextual Teaching and Learning (CTL) pada pokok bahasan segi empat dan segitiga. Untuk mengetahui respon siswa terhadap pembelajaran pendekatan Contextual Teaching and Learning (CTL) pada pokok bahasan segi empat dan segitiga. Untuk mengetahui peningkatan hasil belajar siswa setelah pembelajaran pendekatan Contextual Teaching and Learning (CTL) pada pokok bahasan segi empat dan segitiga.

\section{Metode Penelitian}

Penelitian ini menggunakan

Penelitian Tindakan Kelas. Menurut Arifin (2011), Penelitian Tindakan Kelas adalah sebagai suatu proses penyelidikan ilmiah dalam bentuk refleksi diri yang melibatkan guru dalam situasi pendidikan tertentu dengan tujuan memperbaiki pemahaman dan keadilan tentang situasi atau praktik pendidikan, memahami tentang praktik yang dilakukan, dan situasi-situasi dimana praktik itu dilaksanakan.

Sedangkan menurut Sukardi (2003)

Penelitian tindakan adalah cara suatu kelompok atau seseorang dalam mengorganisasi suatu kondisi sehingga mereka dapat mempelajari pengalaman mereka dan membuat pengalaman mereka dapat diakses oleh orang lain.

Penelitian tindakan mempunyai beberapa karakteristik yang sedikit berbeda bila dibandingkan dengan penelitian formal lainnya. Menurut Sukardi (2003), beberapa karakteristik penting tersebut di antaranya, seperti:

a) Problem yang dipecahkan merupakan persoalan praktis yang dihadapi peneliti dalam kehidupan profesi sehari-hari.

b) Peneliti memberikan perlakuan atau treatment yang berupa tindakan yang terencana untuk memecahkan permasalahan dan sekaligus meningkatkan kualitas yang dapat dirasakan implikasinya oleh subjek yang diteliti. c) Langkah-langkah penelitian yang direncanakan selalu dalam bentuk siklus, tindakan atau daur yang memungkinkan terjadinya kerja kelompok maupun kerja mandiri secara intensif.

d) Adanya langkah berfikir reflektif atau reflective thingking dari penelitian baik sesudah maupun sebelum tindakan. Reflective thingking ini penting untuk melakukan retrospeksi (kaji ulang) terhadap tindakan yang telah diberikan dan implikasinya yang muncul pada subjek yang diteliti sebagai akibat adanya penelitian tindakan.

Jenis penelitian tindakan bertujuan untuk mewujudkan proses penelitian yang mempunyai manfaat ganda baik bagi peneliti yang dalam hal ini mereka memperoleh informasi yang berkaitan dengan permasalahan, maupun pihak subjek yang diteliti dalam mendapatkan manfaat langsung dari adanya tindakan nyata (Sukardi, 2003).

Untuk mewujudkan tujuan - tujuan tersebut, Penelitian Tindakan Kelas dilaksanakan dalam bentuk siklus yang terdiri dari empat tahapan, yaitu planing, action, observation / evaluation, dan reflection. Kegiatan dilakukan di SMP Negeri Satu Atap 1 Camplong Kabupaten Sampang pada semester 2 tahun pelajaran 2014/2015 di kelas VII. Kegiatan difokuskan pada kelas VII dengan jumlah siswa sebanyak 37 orang.

Desain penelitian "Penggunaan Pendekatan Contextual Teaching and Learning (CTL) Untuk meningkatkan hasil belajar siswa kelas VII SMP Negeri Satu Atap 1 Camplong pada pokok bahasan segi empat dan segitiga" akan dilakukan dengan beberapa siklus sampai penelitian ini berhasil. Namun,dalam penelitian ini hanya melakukan 2 siklus. Dimana, materi pembelajaran yang akan diajarkan pada siklus I adalah segiempat dan segitiga. Sedangkan materi pembelajaran yang akan diajarkan pada siklus II adalah keliling dan luas persegi. Peneliti berperan sebagai pengajar di dalam kelas. Peneliti dibantu oleh 2 kolabolator. Kolabolator pertama yaitu wali kelas VII sebagai pengamat I 
aktivitas siswa dalam proses belajar mengajar. Kolabolator kedua yaitu teman aktivitas siswa dalam proses belajar sejawat yang berperan sebagai pengamat II mengajar.

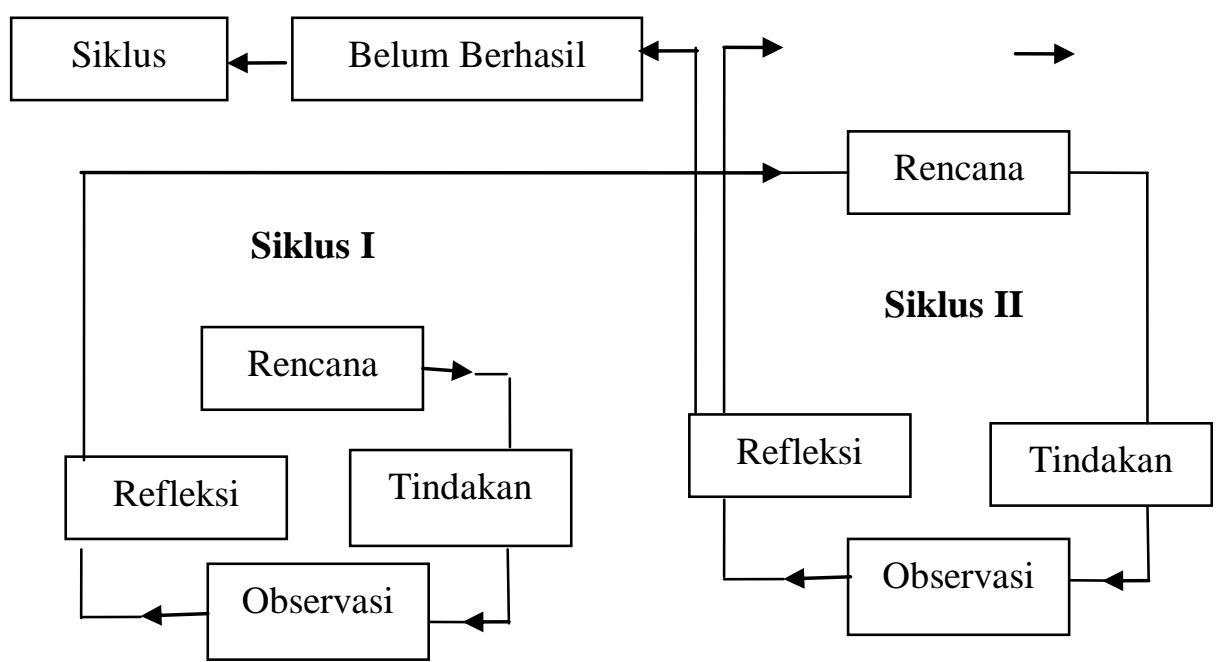

Diagram: Alur Siklus Penelitian Tindakan (Mulyasa, 2009)

Siklus II dilaksanakan sebagai perbaikan dari siklus I, terutama jika terjadi kekurangan dalam perencanaan dan tindakan pada siklus I. Jika target ketuntasan belajar belum tercapai, siklus kedua akan dilaksanakan. Penentuan subjek dalam penelitian ini menggunakan subjek populasi yaitu semua subjek merupakan subjek penelitian. Dalam penelitian ini peneliti menggunakan teknik pengumpulan data dengan Metode observasi, angket dan metode tes.

Setelah semua perangkat pembelajaran selesai ditulis, selanjutnya dilakukan validasi (penilaian) oleh para ahli yang berkompeten untuk menilai perangkat pembelajaran dan memberi masukan atau saran, guna penyempurnaan. Validator yang dipilih adalah 2 orang guru Sekolah Menengah Pertama Negeri Satu Atap 1 Camplong dengan pertimbangan telah mengetahui kondisi siswanya. Validasi ini secara umum mencakup kebenaran substansi, kesesuaian dengan tingkat berpikir siswa dan kesesuaian dengan prinsip, dan pembelajaran pendekatan Contextual Teaching And Learning. Data yang dikumpulkan dari lembar validasi perangkat pembelajaran yang telah divalidasi oleh validator terdiri dari : (a) Rencana Pelaksanaan Pembelajaran, (b)
Lembar Tes, (c) Lembar Kerja Siswa (LKS), (d) Angket, (e) Observasi.

Untuk memperoleh data dengan kelayakan penggunaan pendekatan pembelajaran Contextual Teaching and Learning (CTL) dalam pengajaran matematika, digunakan analisis data deskriptif dengan menghitung:

\section{a. Observasi}

Metode observasi ini digunakan untuk mengetahui aktivitas siswa di kelas selama penggunaan Contextual Teaching And learning. Sedangkan kriteria penilaiannya adalah:

1. Nilai $4=$ Siswa melakukan dengan sangat baik

2. Nilai $3=$ Siswa melakukan dengan baik

3. Nilai $2=$ Siswa melakukan dengan kurang baik

4. Nilai 1 = Siswa tidak melakukan sama sekali

Untuk menghitung peneliti menggunakan rumus : $\quad \bar{x}=\frac{2 x_{i}}{n}$

(Sudjana dalam khalifah, 2014:34)

\section{Keterangan:}

$$
\begin{aligned}
& \bar{x}=\text { mean (rata-rata) } \\
& \sum x_{i}=\text { jumlah data ke-i } \\
& n=\text { banyak data }
\end{aligned}
$$




\section{b. Angket}

Metode angket ini digunakan untuk mengetahui respon siswa di kelas selama penggunaan Contextual Teaching And learning, peneliti menggunakan rumus penelitian dalam bentuk prosentase yang dihitung dengan rumus:

$R_{i}=\frac{s_{i}}{n} \times 100 \% \quad$ (Trianto dalam

Khalifah, 2014:34)

Keterangan :

$R_{i}=$ persentase siswa yang menjawab "ya"

$S_{i}=$ banyak siswa yang menyatakan "ya"

$n=$ jumlah siswa (responden)

Respon siswa dianggap positif jika presentase rata-rata jawaban siswa $\geq$ $60 \%$, sedangkan respon siswa dianggap negatif jika prosentase rata-rata jawaban siswa $<60 \%$.

\section{c. Tes}

Menurut Trianto, 2009 dalam Khalifah (2014) Ketuntasan hasil belajar siswa dapat dilihat dari hasil tes yang dilakukan setelah kegiatan pembelajaran berlangsung. Seorang siswa secara individu dikatakan tuntas belajaranya apabila ia memperoleh nilai minimal 70 . Penelitian ini dikatakan tuntas apabila kelas tersebut terdapat $\geq 85 \%$ siswa telah mencapai ketuntasan yang dapat dicari dengan menggunakan rumus:

Ketuntasan belajar secara klasikal = $\frac{2 x}{\sum N} \times 100 \%$ (Trianto, 2009: 241)

Keterangan :

$\sum x$ : Jumlah siswa yang tuntas belajar secara individu.

$\sum \mathrm{N}$ : jumlah siswa dalam satu kelas Dalam penelitian ini siklus dihentikan jika suatu kelas dikatakan memenuhi target ketuntasan apabila kelas tersebut terdapat $\geq 85 \%$ siswa telah mencapai ketuntasan

\section{Hasil dan Pembahasan}

Data yang diperoleh dari hasil observasi aktifitas belajar siswa dalam pembelajaran matematika di SMP Negeri Satu Atap 1 Camplong mengalami peningkatan seperti yang terlihat pada gambar 1. Pada siklus I nilai rata-rata kemandirian belajar siswa adalah 3,2 dengan kategori baik sedangkan pada siklus II nilai rata-rata kemandirian belajar siswa meningkat menjadi 3,6 dengan kategori sangat baik. Data yang diperoleh dari hasil angket respon siswa menunjukkan respon positif terhadap pembelajaran matematika dengan pendekatan Contextual Teaching And Learning (CTL). Hal ini terlihat pada gambar 2 bahwa persentase respon positif siswa meningkat yaitu pada siklus I sebesar 77\% dan pada siklus II menjadi 79\%.

Kemudian dari gambar 3 terlihat bahwa nilai dari hasil belajar siswa dengan menggunakan pendekatan Contextual Teaching and Learning (CTL) pada materi segi empat dan segitiga kelas VII SMP Negeri Satu Atap 1 Camplong selama dua siklus ditemukan bahwa hasil belajar siswa mengalami peningkatan dari siklus I ke siklus II. Pada siklus I nilai rata-rata siswa adalah 70 dengan persentase ketercapaian secara klasikal sebesar 49\%. Karena persentase ketercapaian secara klasikal< $85 \%$, maka dapat disimpulkan bahwa pada siklus I belum mendapatkan hasil yang baik dan belum mencapai target. Oleh karena itu, perlu dilakukan tindakan berikutnya yaitu siklus II, untuk menindak temuan temuan dari hasil refleksi siklus I.

Kemudian pada siklus II mengalami peningkatan yaitu nilai rata-rata siswa menjadi 75 dengan persentase ketercapaian secara klasikal sebesar $86,48 \%$. Persentase hasil belajar siswa secara klasikal mengalami peningkatan sebesar 37,48\%. Sehingga hasil belajar siswa pada materi segi empat dan segitiga dengan menggunakan strategi pendekatan Contextual Teaching And Learning (CTL) mengalami peningkatan. 


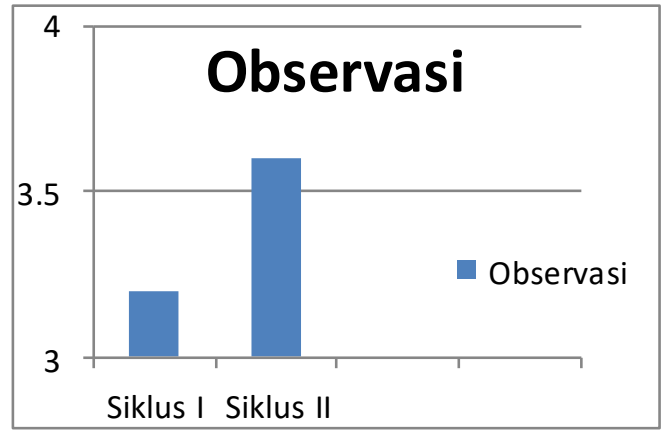

Grafik 1. Data Hasil Observasi Aktifitas pada Siklus I dan Siklus II

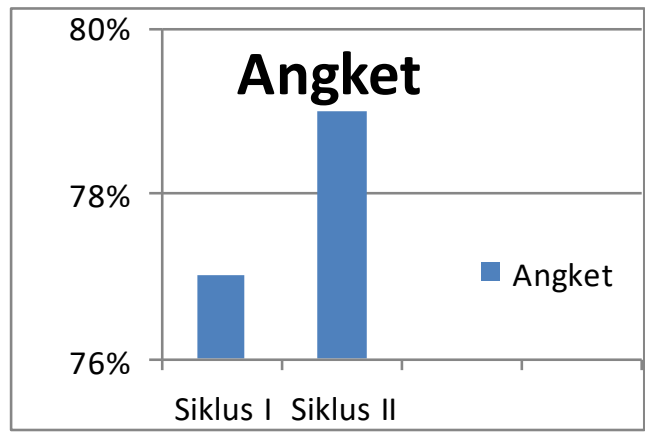

Grafik 2. Data Hasil Angket pada Siklus I dan Siklus II

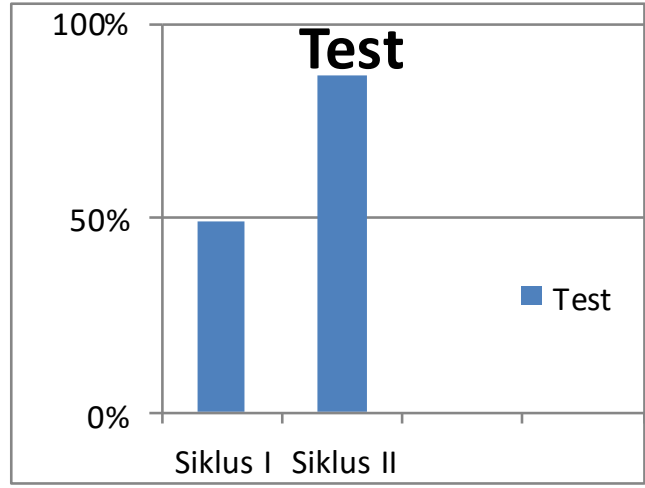

\section{Grafik 3. Data Hasil Test pada Siklus I dan Siklus II}

Berdasarkan hasil yang telah diperoleh di atas, pendekatan Contextual Teaching And Learning (CTL) pada materi segi empat dan segitiga mampu meningkatkan hasil belajar siswa. Hal ini sesuai dengan penelitian Rahmawati (2018) penelitian dengan fokus penerapan model CTL untuk meningkatkan hasil belajar siswa dengan metode studi kepustakaan, menunjukkan bahwa model CTL direkomendasikan untuk dapat diterapkan pada mata pelajaran matematika.

Perbedaan penelitian ini dengan penelitian yang dilakukan oleh Rahmawati (2018) yaitu subjek dan mata pelajaran. Pembelajaran pendekatan CTL merupakan konsep belajar yang membantu guru mengaitkan antara materi yang diajarkannya dengan situasi dunia nyata siswa dan mendorong siswa membuat hubungan antara pengetahuan yang dimilikinya dengan penerapannya dalam kehidupan mereka sehari hari (Trianto, 2007). Dengan begitu tujuan pembelajaran akan tercapai. Menurut Zayyadi (2019), salah satu tujuan pembelajaran matematika yang diharapkan muncul adalah kemampuan memahami konsep matematika.

Ciri khas Contextual Teaching and Learning (CTL) ditandai oleh tujuh komponen utama yaitu 1) Constructivism; 2) Inquiry; 3) Questioning; 4) Learning Community; 5) Modelling; 6) Reflection; dan 7) Authentic Assessment; (Rusman, 2011) dan hal serupa diungkapkan oleh Trianto (2007).

Hasil belajar adalah perolehan nilai akhir siswa dalam segala hal setelah ia menerima pengalaman belajarnya disekolah baik itu berupa kemampuan kognitif (pengetahuan dan ingatan), kemampuan afektif (penerimaan dan memberikan respon) maupun kemampuan psikomotorik (keterampilan dan kemampuan bertindak), dimana nilai yang akan diambil yaitu dari siswa berkemampuan kognitif dan afektifnya selama proses pembelajaran.

Hal di atas sesuai dengan pendapat Suprijono, (2009) bahwa hasil belajar adalah perubahan perilaku secara keseluruhan bukan hanya salah satu aspek potensi kemanusiaan saja. Artinya, hasil pembelajaran yang dikategorikan oleh para pakar pendidikan sebagaimana tersebut diatas secara fragmentaris atau terpisah, melainkan komprehensif.

\section{Simpulan dan Saran Simpulan}

Berdasarkan hasil penelitian dan pembahasan yang telah diuraikan, dapat diambil kesimpulan setelah pelaksanaan 
pembelajaran dengan pendekatan Contextual Teaching and Learning (CTL) bahwa:

1) Hasik observasi aktifitas siswa dari kedua observer pada siklus I nilai rataratanya adalah 3,2 dengan kategori baik sedangkan pada siklus II nilai rata-ratanya adalah 3,6 dengan kategori sangat baik.

2) Hasil angket respon siswa memberikan respon positif terhadap pembelajaran matematika dengan pendekatan Contextual Teaching And Learning (CTL). Hal ini terlihat dari persentase hasil angket respon siswa pada siklus I yaitu $77 \%$ sedangkan persentase hasil angket respon siswa pada siklus II yaitu $79 \%$.

3) Hasil belajar siswa kelas VII SMP Negeri Satu Atap 1 Camplong dalam pembelajaran matematika dari siklus I ke siklus II mengalami peningkatan hasil belajar dalam persentase sebesar $37,48 \%$. Pada siklus I nilai rata-rata siswa adalah 70 dengan persentase ketercapaian secara klasikal sebesar $49 \%$ pada siklus II nilai rata-rata siswa adalah 75 dengan persentase ketercapaian secara klasikal sebesar $86,48 \%$.

\section{Saran}

Pembelajaran matematika dengan pendekatan Contextual Teaching And Learning (CTL) dapat digunakan sebagai salah satu alternatif atau upaya untuk meningkatkan kemandirian belajar siswa. Untuk penelitian-penelitian berikutnya, bentuk kegiatan pembelajaran dapat dikembangkan kembali supaya lebih baik dan menarik sehingga siswa jauh lebih semangat dalam mengikuti proses pembelajaran, dan pada akhirnya hasil belajar siswa yang diperoleh dapat lebih optimal. Pembelajaran pendekatan Contextual Teaching And Learning (CTL) harus memperhatikan situasi kondisi dalam kelas dan bisa menggunakan contextual yang tepat.

Demikian saran penulis dalam penelitian ini, mudah-mudahan hasil penelitian ini dapat bermanfaat bagi perkembangan dunia pendidikan pada umumnya.

\section{Daftar Pustaka}

Arifin, Z. 2011. Penelitian Pendidikan. Jakarta : Rosda.

Khalifah, N.S. 2014. Upaya Meningkatkan Hasil Belajar Siswa Melalui Strategi Pembelajaran Think-Talk-Write (TTW) pada Materi Bangun Ruang Sisi Datar Kelas VIII SMP Negeri 2 Pademawu Pamekasan Tahun Pelajaran 2013/2014. (Skripsi tidak dipublikasikan). Unira Pamekasan Jawa Timur, Pamekasan, 16 Agustus.

Mulyasa, H.E. 2009. Penelitian Tindakan Sekolah. Jakarta: PT Remaja Rosdakaya.

Polya, G. 1973. How to Solve it. $2^{\text {nd }}$ Ed. Princeton University Press, ISBN 0691-08097-6.

Rahmawati, T. 2018 Penerapan Model Pembelajaran CTL untuk Meningkatkan Hasil belajar Siswa Sekolah Dasar pada Mata Pelajaran IPA. JIPP Universitas Pendidikan Ganesha, Vol 2, No 1. DOI: 10.23887/jipp.v2i1.13765.

Rusman. 2011. Model-model Pembelajaran: Mengembangkan Profesionalisme Guru. Jakarta: PT Raja Grafindo Persada.

Suprijono, A. 2009. Cooperative Learning Teori Aplikasa Paikem. Yogyakarta : Pustaka Belajar.

Sukardi. 2003. Metode Penelitian. Jakarta: PT Bumi Aksara

Trianto. 2007. Model-model Pembelajaran Inovatif Berorientasi Konstruktivistik. Jakarta : Prestasi Pustaka.

Trianto. 2009. Mendesain Model Pembelajaran Inovatif Progresif. Jakarta: Kencana. 
Zakaria, A., Budiarto, M.T., \& Sulaiman, R. 2018. The Relational Thinking Process of Secondary School Student with High Mathematical Ability in Solving Mathematics Problem. Atlantis Press. Advances in Intelligent Systems Research (AISR), volume 157.

Zayyadi, M. 2014. Pengaruh Strategi Pembelajaran Peningkatan Kemampuan Berpikir Terhadap Hasil Belajar. INTERAKSI: Jurnal Kapendidikan.
Zayyadi, M. 2016. Pengaruh Strategi Pembelajaran Peningkatan Kemampuan Berpikir (SPPKB) Terhadap Hasil Belajar Matematika Siswa SMP 1 Pamekasan. Jurnal Pendidikan Fisika.

Zayyadi, M. 2019. Pengembangan Lembar Kerja Siswa Berbasis Etnomatematika dalam Membangun Pemahaman Konsep Siswa. Jurnal Pendidikan Matematika dan IPA, (10)2. 